Dunamis: Jurnal Teologi dan Pendidikan Kristiani

Volume 6, Nomor 1 (Oktober 2021)

ISSN 2541-3937 (print), 2541-3945 (online)

https://www.sttintheos.ac.id/e-journal/index.php/dunamis

DOI: 10.30648/dun.v6i1.646

\title{
[Resensi Buku] A Pentecostal Political Theology for American Renewal: Spirit of the Kingdoms, Citizens of the Cities
}

\author{
Yushak Soesilo \\ Program Studi Teologi, Sekolah Tinggi Teologi Intheos Surakarta \\ yushak@sttintheos.ac.id
}

\section{IDENTITAS BUKU}

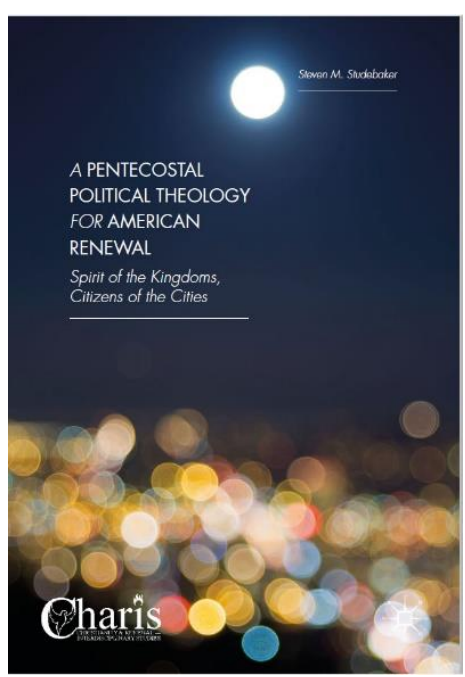

Judul Buku : A Pentecostal Political Theology for American Renewal: Spirit of the Kingdoms, Citizens of the Cities

Bahasa : Inggris

Penulis : Steven M. Studebaker

ISBN : : 978-1-137-48016-3 (e-book)

Terbit : 2016

Tebal : xiii +292 halaman

Penerbit : Palgrave Macmillan 


\section{TINJAUAN BUKU}

Steven M. Studebaker menawarkan suatu gagasan teologi politik yang khas bagi kaum Pentakostal. Gagasan tersebut tentu adalah sebuah terobosan besar, mengingat bahwa kaum Pentakostal pada umumnya dikenal sebagai golongan Kristen yang ahistoris dan apolitis oleh karena pemahaman spiritualisasinya atas Alkitab. Tidak dapat disangkal bahwa kelompok Pentakostal mendasarkan imannya atas pemahaman eskatologis yang bersifat milinealis. Hidup di dunia ini dianggap tidak lebih penting daripada hidup dalam kekekalan. Mengerjakan perkara-perkara rohani, seperti berdoa, berpuasa, terlibat dalam pelayanan di gereja, adalah lebih utama dibandingkan dengan mengerjakan pekerjaan-pekerjaan yang dianggap bersifat duniawi. Penginjilan dengan tujuan memenangkan jiwa dipandang sebagai pelayanan yang utama dan sebenarnya dibandingkan dengan mewujudkan visi Kerajaan Allah dalam dunia sekuler. Dalam bukunya tersebut, Studebaker mengkritik pandangan Pentakostal yang ahistoris dan apolitis tersebut, dan menawarkan suatu teologi yang berasal dari kekayaan dalam diri teologi Pentakosta itu sendiri. Ia menawarkan gagasan Teologi Politik Roh (Political Theology of Spirit).

Teologi Politik Roh itu sendiri sejalan dengan pemahaman kaum Pentakostal akan karya Roh Kudus. Meskipun kaum Pentakostal mengakui kesetaraan oknum-oknum dalam Trinitas, namun tidak dapat disangkal pada praktiknya oknum Roh Kudus ditempatkan dalam porsi yang lebih besar daripada kedua pribadi lainnya (Bapa dan Putera). Kaum Pentakostal menerima baptisan Roh Kudus sebagai pengalaman kedua, setelah kelahiran baru melalui Roh Kudus. Kelompok ini juga memegang teguh bahwa karunia-karunia supranatural yang mengikuti baptisan Roh Kudus masih terus berlaku hingga sampai saat ini dan menjadi kerinduan bagi mereka untuk mendapatkannya. Namun demikian, karunia-karunia tersebut dipahami hanya sebatas untuk mengembangkan pelayanan-pelayanan rohani atau yang bersifat gerejawi dalam rangka perintisan maupun pertumbuhan gereja. Keterlibatan aktif dalam karya-karya non-rohani dianggap penting, namun hanya dinilai sebagai sementara dan dalam rangka mempersiapkan atau sebagai bekal bagi kehidupan yang sebenarnya, yaitu hidup kekal di sorga.

Sikap tersebut oleh Studebaker dianalogikan dengan dikotomi antara Babel dan Yerusalem Baru. Babel adalah gambaran yang merepresentasikan kota-kota dan bangsa-bangsa di dunia ini dengan segala aktivitas di dalamnya. Sedangkan Yerusalem Baru merepresentasikan sorga. Babel adalah simbol dosa. Dari pemahaman tersebut muncul salah satu sikap kekristenan yang 
paling popular, yaitu mengisolasi diri dari dunia, yang diwakili oleh tokoh-tokoh seperti John Howard Yoder, Stenley Hauwerwas, maupun Walter Brueggemann. Bagi mereka, ada hubungan yang bersifat oposisional dan biner antara gereja dengan dunia, sehingga Yoder menawarkan gagasan komunitas alternatif, yaitu komunitas gereja yang dibentuk oleh nilai-nilai $\mathrm{Ke}$ rajaan Allah, sedangkan Brueggemann mendorong sikap subversif, yaitu tidak berkolaborasi dengan kultur dominan. Studebaker melihat bahwa gagasan-gagasan terebut berangkat dari pemahaman bahwa orang Kristen adalah warga asing (resident alien) di dunia ini, yang memiliki kewarganegaraan sejatinya di sorga.

Studebaker memasukkan kelompok yang berpandangan cenderung subversif terhadap imperium Kristen (Amerika Serikat) sebagai kelompok Kristen pinggiran. Ia menuduh mereka senang dengan keruntuhan imperium Kristen. Menurutnya, Tuhan memanggil Adam untuk bekerja dan memelihara kebun (Kej. 2:15), dan Eden adalah tempat dengan kehidupan yang melimpah. Oleh karena itu, kemiskinan bukanlah sesuatu yang aspirasional dan paradigma normatif bagi kekristenan. Mengaspirasi kemakmuran tidaklah berarti dijajah oleh imperium neo-liberal. Tuhan menciptakan dunia materi penuh sukacita dan melimpah, bukan kurang dan penuh penderitaan.
Orang Kristen harus membela dan bertindak bagi orang miskin dan maginal oleh karena kenyataan adanya kegemaran untuk mengeksploitasi yang lainnya demi perluasan kekayaan diri sendiri. Untuk itu, mereka harus mempergunakan modal sosial dan keuangan untuk memberdayakan mereka yang tidak berdaya. Roh Pentakosta bukanlah Roh kekurangan. Peradaban dan budaya imperium dapat menjadi alat bagi penindasan dan ketidakadilan, namun sebaliknya, mereka juga menyediakan perawatan kesehatan, program bantuan sosial, sistem keadilan, dan sebagainya. Benar bahwa gereja harus menawarkan cara hidup alternatif atas disfungsi yang sering ditemukan dalam budaya di sekitarnya. Namun demikian, tidaklah perlu untuk menganggap bahwa ketunawismaan secara kultural (status sebagai pengungsi) sebagai metafor yang normatif bagi kekristenan dalam hubungannya dengan masyarakat dan kultur.

Bagi Studebaker, sikap yang demikian tidak sejalan dengan sifat karya Roh yang berkarya secara universal dan kontinum. Karya Roh menurutnya tidak sejalan dengan diskontinuitas dalam teologi biner, yang memisahkan antara paham penciptaan dan penebusan. Istilah teologis tersebut sering digunakan untuk memisahkan karya penciptaan Allah sebagai pernyataan umum (common grace) dan karya penebusan sebagai pernyataan khusus (special grace), se- 
hingga di dalamnya terkandung pemisahan antara kerja duniawi dan kerja rohani. Teologi biner yang diskontinum memang tidak serta merta mempertentangkan kedua dimensi tersebut, namun berimplikasi kepada pemisahan program ilahi. Kerja di dunia ini seberapapun berharganya masih berada di bawah gereja, sehingga orang Kristen seharusnya mencurahkan devosinya pada disiplin spiritual, kesalehan pribadi, dan pelayanan gerejawi. Teologi biner tersebut menurutnya tidak hanya terasa ganjil bagi Teologi Politik Pentakosta, tetapi juga terhadap realitas hidup manusia. Inkarnasi membuktikan bahwa Allah dapat hidup dalam kultur imperium Romawi. Yesus menolak cara hidup imperium, namun hidup dan melakukan pelayanannya dalam kultur masyarakat Romawi. Tuhan menciptakan manusia untuk menjadi penghasil budaya. Budaya selalu bermuatan kerusakan karena dosa, yang karena itu membutuhkan penebusan. Budaya adalah cara manusia memanifestasikan hembusan Roh pada diri manusia sebagai citra ilahi. Ketika manusia menciptakan budaya yang mengembangkan kehidupan, maka hal itu membawa perubahan pada chaos primordial kepada Eden, sebagaimana penciptaan dalam Kejadian 1-2. Konsekuensinya, hidup di dunia ini mengandung kontinuitas di kehidupan yang akan datang. Pola mendasar dan aktivitas hidup di Babel dan Yerusalem Baru lebih banyak kemiripannya daripada perbedaannya.
Penciptaan yang dinarasikan dalam Alkitab bukanlah sebuah penciptaan dalam pengertian filosofis, tetapi dalam pengertian soteriologis. Penciptaan adalah sekaligus penebusan. Roh menjadi katalis sentral dalam karya penciptaan Allah, sehingga sekaligus menjadi karya penebusan. Kejadian 1:2 memulai narasi penciptaan yang menebus tersebut dengan karya Roh Allah yang melayang-layang di atas permukaan air. Karya Roh tersebut membebaskan elemen utama dari kegelapan dan ketidakteraturan dan menghasilkan ciptaan. Demikian juga dalam Kejadian 8:1, yang dapat disebut sebagai penciptaan 2.0, Roh (ruach) berhembus sehingga membuat air turun, membebaskan daratan dari genangan air. Laut atau deep water adalah sebagai simbol kekacauan, yang dengan demikian kegiatan penciptaan adalah sekaligus merupakan tindakan penebusan. Mazmur 74 menangkap natur penebusan dari teologi penciptaan Ibrani. Tindakan penciptaan YHWH dipahami sebagai yang membawa harmoni, keteraturan dan hidup di tengah-tengah samudera yang menakutkan. Demikian juga dalam Mazmur 104:30. Kisah penciptaan yang menebus juga dapat ditemukan dalam pemberitaan Yesaya 42:5-7; 32:15; 51:9-11. Oleh karena itu penciptaan adalah tindakan pertama dari pembebasan dan penebusan ilahi. Penciptaan tidak dapat dipisahkan dari penebusan. Pernyataan umum (common grace) tidak dipisahkan dari pernyataan khusus (special 
grace). Partisipasi orang Kristen dalam aktivitas kreatif di dunia ini adalah sekaligus dapat dipahami sebagai partisipasi dalam karya penciptaan oleh Roh yang menebus.

Perjanjian Baru juga mengafirmasi kontinuitas antara penciptaan dan penebusan. Kisah Para Rasul 2:1-4, yang mengisahkan orang-orang percaya yang dipenuhi oleh Roh Kudus dan kemudian berbicara dengan berbagai-bagai bahasa, menggambarkan bagaimana Roh Kudus memberikan kuasa untuk melakukan pelayanan publik. Namun demikian, meskipun Pentakosta menyedikan kehidupan Allah dalam Roh, pemenuhannya terjadi di langit yang baru, bumi yang baru, dan Yerusalem baru dari Kerajaan Allah yang kekal. Pentakosta adalah ambang dari Kerajaan Allah-kerajaan yang datang dalam pencurahan Roh, namun pemenuhannya menantikan penyempurnaan final Kerajaan Allah dalam ciptaan baru. Lebih daripada itu, Pentakosta adalah zona liminal individu dan partisipasi kosmis dalam kedatangan Kerjaan Allah. Janji Pentakosta meliputi pembaharuan ciptaan (Kis. 2:17-21 yang mengutip Y1. 2:28-32). Dalam Yoel tersebut janji pencurahan Roh secara universal didahului dengan pemulihan bangsa dan tanah Israel (Y1. 2:18-27). Pembaruan dari Roh merestorasi tanah yang tandus menjadi subur. Visi penebusan tersebut bukanlah terjadi di dunia yang lain, tetapi di dunia ini. Meskipun penekanan yang popular adalah bahwa keselamatan terutama tentang penebusan dosa dan pergi ke sorga, namun Roh Pentakosta datang untuk membarui hidup di dunia ini. Pembaruan manusia tidak dapat dilepaskan dari pembaruan tanah. Paulus juga menyampaikan visi kosmis penebusan, bahwa bukan hanya jiwa manusia saja, tetapi ciptaan juga dilahirkan kembali (bd. Rm. 8:21).

Tuhan menciptakan manusia untuk hidup di dunia ini, bukan hanya untuk gereja dan sorga saja. Mandat penatalayanan (Kej. 1:28) mendahului kejatuhan ke dalam dosa. Manusia diciptakan untuk memproduksi budaya, bukan sebagai konsekuensi dosa, tetapi sebagai bagian dari hidup mereka bersama Tuhan di dunia ini. Roh berhembus ke dalam kehidupan manusia di dunia ini (bd. Kej. 2:7), tidak hanya agar manusia dapat eksis semata, tetapi supaya manusia dapat hidup di dunia ini. Hidup berarti melakukan berbagai aktivitas kehidupan di dunia ini. Roh tidak menciptakan dunia dan menghembuskan hidup kepada manusia hanya untuk tertarik pada dimensi spiritual dalam hidup mereka. Babel dan Yerusalem Baru dalam Alkitab memang merupakan suatu kontras. Namun demikian, masalahnya bukanlah terletak pada Babel itu sendiri. Kotanya beserta dengan segala aktivitas sehari-hari tidaklah jahat. Budaya, peradaban manusia adalah baik. Secara intrinsik itu semua adalah hidup yang diberikan oleh 
Roh dan ditebus di dalam Yerusalem Baru. Yang merupakan masalah adalah cara hidup Babel. Penghancuran Babel bukanlah penghapusan kehidupan yang berlangsung di dalamnya, namun cara/tatanan hidup Babel (bd. Why. 21:4). Oleh karena itu, orang Kristen adalah warga dalam kehidupan di bumi ini, tetapi sekaligus pendatang atau orang asing bagi cara hidup Babel.

Hidup di dunia ini bukanlah sebuah persinggahan menuju hidup rohani yang sesungguhnya di sorga. Penciptaan manusia dalam setting dunia Eden, mendemonstrasikan bahwa dunia ini, bukan sorga, adalah merupakan impian Tuhan bagi kehidupan manusia. Oleh karena manusia diciptakan seturut gambar dan citra Allah, maka seluruh manusia adalah agen-agen yang menjalankan pemerintahan dan penatalayanan di bumi atas nama Allah. Citra ilahi adalah termasuk kapasitas intelektual dan moral yang unik untuk melaksanakan karya kreatif dan produktif di dunia yang Tuhan maksudkan bagi manusia. Manusia ada untuk menggarap dan memelihara dunia mereka. Dosa tidaklah menghapus kapasitas kreatif manusia sebagai citra Allah yang dihembusi oleh Roh.

Hidup di dunia ini adalah cara konkret bagi manusia mempergunakan kapasitas yang diberikan oleh Roh untuk menjadi

1 Amos Yong, Discerning the Spirit(s): A Pentecostal-Charismatic Contribution to Christian Theology of Religions, ed. John Christopher citra Allah. Musik rock, tarian, film, dsb, dapat merupakan manifestasi dari Roh. Namun demikian, tidak semua yang terjadi di dunia ini berasal dari Roh. Untuk dapat memahaminya sebagai karya Roh Tuhan perlu memahaminya dalam kriteria Kristologis. Kristologi membutuhkan pneumatologi. Roh Kudus menghasilkan hidup inkarnasi Anak Allah dalam diri Yesus Kristus. Karya universal dan kekal Roh dalam hidup manusia yang dimulai dari Adam hadir dalam ekspresi yang paling radikal dalam pribadi sejarah Yesus. Roh Kudus menginkarnasikan Anak Allah ke dalam Yesus Kristus. Roh Kudus bukanlah yang berinkarnasi itu sendiri, tetapi agen inkarnasi, yang dalam cara yang sama Roh membangkitkan hidup dalam diri manusia sebagai citra Allah. Yesus adalah kepenuhan dari citra Allah. Kristus adalah puncak dari karya kreatif-redemtif oleh Roh. Ketika karya manusia merefleksikan karakter Kristologis, itu adalah produk dari Roh yang memberikan kapasitas untuk menjadi citra Allah.

Upaya menilai karya Roh dengan kriteria Kristologis tersebut tentu adalah merupakan gagasan yang selangkah lebih maju dibandingkan dengan yang pernah dipikirkan oleh Amos Yong. Yong membagi karya pneumatologis dalam tiga kategori, yaitu kehadiran ilahi, aktifitas ilahi, dan absensi ilahi. ${ }^{1}$ Sebagaimana Studebaker, Yong

Thomas, Rickie D. Moore, and Steven J. Land (Sheffield: Sheffield Academic Press, 2000). 
juga mengemukakan bahwa tidak semua realitas adalah karya Roh Allah. Itulah yang disebutnya dengan absensi ilahi. Ia menyebutkan bahwa kebebasan yang destruktif, ketidakadilan, alienasi, dan penindasan-penindasan adalah bentuk absensi ilahi, yang kemudian disebutnya juga sebagai karya demonic spirit. Studebaker dengan cerdas merangkumnya dalam satu kriteria definit, karakter Kristologis.

Sebagaimana judul bukunya, Studebaker mengembangkan gagasan teologi politiknya dalam konteks Amerika Serikat. Ia melihat bahwa sebagaimana kaum Pentakosta dengan pengalaman baptisan Roh Kudusnya menganggap diri sebagai kelompok elit di kalangan gereja/ Kristiani, demikian juga Amerika, dalam paham sekulernya, menganggap diri sebagai bangsa elit di antara bangsa-bangsa lain di dunia. Nilai-nilai demokrasi dan liberalisme Amerika dianggap seperti Injil yang harus juga dibawa kepada bangsa-bangsa lainnya bagaimanapun caranya, termasuk, jika perlu, dengan kekuatan militer. Dalam Bab 8 yang berjudul "Blessed but Not Special," ia mengkritik sikap Amerika tersebut. Baginya kenyataan bahwa Amerika sebagai negara besar, dan tentu saja sebagai negara dengan mayoritas penduduk Kristen, adalah merupakan berkat Tuhan, namun tidak berarti bahwa Amerika kemudian dapat melakukan apa saja kepada bangsa lain untuk mengikuti nilai-nilai yang diyakininya benar karena menganggap diri sebagai yang terpilih (the chosen).

Namun demikian, di Bab 9 yang berjudul "Global Leadership without Hubris," sikap Studebaker nampak berbeda dibandingkan dengan sikap yang ia tunjukkan di Bab 8. Apabila di Bab 8 ia mengkritik Amerika yang bertindak selayaknya penguasa dan polisi dunia, di Bab 9 ia tidak menyangkal bahwa nilai-nilai politik, ekonomi, dan peradaban Amerika adalah pilihan yang terbaik di antara pilihan-pilihan lainnya yang ada. Ia menyebut demokrasi dan liberalisme Amerika masih lebih baik dibandingkan dengan sistem negara komunis-sosialis atau totalitarian-religius. Semua bangsa adalah Babel, dan Amerika, yang meskipun adalah Babel juga, merupakan pilihan terbaik. Prinsip-prinsip dan praktik politik dan sipil Barat, yang direpresentasikan oleh Amerika, menawarkan suatu kondisi kultural terbaik untuk mewujudkan citra ilahi yang dihembusi oleh Roh dalam lintasan waktu sejarah. Di Amerika siapapun bisa dengan bebas melontarkan kritik, dan bahkan bisa mendapatkan keuntungan finansial dari kritiknya tersebut, oleh karena prinsip kebebasan yang dianut oleh Amerika. Sesuatu yang tidak mungkin akan dapat dialami di negara-negara yang bersistem totalitarian. Oleh karena itu, menurut Studebaker, adalah sah bagi Amerika untuk 
melanjutkan kepemimpinan global dan intervensi internasionalnya dalam rangka membebaskan sipil dari tirani dan intoleransi. Konsekuensinya, kekuatan militer dapat digunakan, asal dengan penuh kehati-hatian dan penuh tanggung jawab.

\section{Kontradiksi dalam pemikiran}

Studebaker tersebut tentunya mengundang kritik tersendiri terhadapnya. Jika di bagian-bagian awal bukunya ia menawarkan gagasan menarik tentang karya Roh yang kreatif-redemtif sekaligus kontinum sebagai kritik terhadap pemikiran "kota di atas bukit," yang dianggapnya bernada triumfalistik, namun di bagian akhir bukunya justru memberikan permakluman terhadap tindakan intervensi Amerika terhadap negara-negara lainnya, bahkan jika itu dilakukan dengan kekuatan militer sekalipun. Memang ia mensyaratkan bahwa tindakan militer itu harus dilakukan dengan penuh kehati-hatian dan bertanggung jawab, namun bagaimana ukuran hati-hati dan bertanggung jawab tersebut? Sebuah ukuran yang akan sangat subjektif dalam pendefinisiannya. Oleh karena Amerika adalah negara adidaya, yang menguasai lembaga-lembaga internasional, maka definisi "hati-hati dan bertanggung jawab" itu akan akan berpotensi tereduksi hanya berdasarkan versi

2 F. Budi Hardiman, Demokrasi Deliberatif: Menimbang "Negara Hukum" Dan "Ruang Publik"
Amerika sendiri. Itu artinya, Studebaker jatuh pada apa yang dikritiknya sendiri, teologi politik yang triumfalistik.

Memegang teguh nilai-nilai kebajikan Kristiani adalah sebuah keharusan, demikian juga dengan upayanya untuk mendiseminasikan nilai-nilai tersebut sebagai bagian dari keyakinan bahwa nilai-nilai tersebut dapat membawa kebaikan dalam kehidupan manusia. Itu juga adalah merupakan panggilan untuk memberitakan kabar baik atau Injil. Namun demikian, hal itu seharusnya dilakukan melalui dialektika komunikatif. Jurgen Habermas membagi tindakan manusia atas tindakan komunikatif dan tindakan strategis. Tindakan komunikatif berorientasi pada pencapaian kesepakatan atau konsensus, sedangkan tindakan strategis berorientasi pada keberhasilan. ${ }^{2}$ Meskipun keduanya adalah merupakan tindakan rasional, namun tindakan komunikatif menggunakan bahasa sebagai medium pemahaman, sedangkan tindakan strategis menggunakan bahasa sebagai alat untuk memaksakan kehendak. ${ }^{3}$ Dengan demikian, sudah seharusnya yang dikedepankan adalah tindakan komunikatif. Sebaik apapun nilai-nilai Kristiani yang kita yakini harus dikomunikasikan dalam sebuah ruang diskursus yang adil. Adil di sini maksudnya adalah setiap

Dalam Teori Diskursus Jurgen Habermas (Yogyakarta: PT Kanisius, 2009), 34-35.

${ }^{3}$ Ibid, 36. 
pihak dengan bebas dan tanpa paksaan dapat mengemukakan gagasannya dan dalam kedudukan yang sejajar. Setiap pihak harus mengedepankan pencapaian pemahaman satu dengan yang lainnya, meskipun tentu saja tidak harus diartikan sebagai persetujuan.

\section{DAFTAR PUSTAKA}

Hardiman, F. Budi. Demokrasi Deliberatif: Menimbang "Negara Hukum" Dan "Ruang Publik" Dalam Teori Diskursus Jurgen Habermas. Yogyakarta: PT Kanisius, 2009.

Yong, Amos. Discerning the Spirit(s): A Pentecostal-Charismatic Contribution to Christian Theology of Religions. Edited by John Christopher Thomas, Rickie D. Moore, and Steven J. Land. Sheffield: Sheffield Academic Press, 2000 . 